\title{
Cancer risk and prognosis in Norway: comparing women in their first marriage with women who have never married
}

\author{
Anne Kvikstad, Lars J Vatten
}

\begin{abstract}
Study objective - The difference in risk of cancer between never married women and married women in their first marriage and whether survival from cancer was any different between the two groups were studied.
\end{abstract}

Design - This was a population based, nested case-control study of cancer in Norwegian women diagnosed between 1966 and 1990, and followed up with regard to overall survival until the end of 1991.

Setting - Norway.

Participants - These were Norwegian women born between 1935 and 1954. The case-control study included 12237 married and 1466 unmarried cases, and 26075 married and 2768 unmarried controls. In the survival analysis, 11943 married and 1473 unmarried cases were included.

Main results - Unmarried women had an overall increased cancer risk $(O R=1 \cdot 13$, $95 \%$ CI $1.05,1.21$ ), which could be attributed to cancer of the ovaries, uterus, brain and haematological malignancies. For cervical and thyroid cancer, the risk was lower than for married women. In the survival analysis, unmarried cases had an overall $26 \%$ increased risk of dying $(H R=$ $1 \cdot 26,95 \%$ CI $1 \cdot 15,1 \cdot 39$ ), after adjustment for age and stage at diagnosis. The increased death rate was seen for cancer of the cervix, lung, and thyroid.

Conclusions - Since most unmarried women were nulliparous, this might explain their increased risk of ovarian and uterine cancer. The increased risk of brain tumours and haematological malignancies may result from selection bias, since disease among unmarried women may cause a large proportion to remain unmarried. The lower survival in unmarried cases may support the hypothesis that psychosocial factors play a role in the prognosis of cancer patients.

\section{(f Epidemiol Community Health 1996;50:51-55)}

Studies of the relationship between marital status and health indicate that there is generally a protective effect of marriage on morbidity and mortality. ${ }^{1-4}$ The results are, however, inconsistent and vary between diseases, race, and gender. ${ }^{58}$ For cancer, comparisons of incidence between marital groups have shown lower rates in married people for many sites. ${ }^{89}$ With regard to case fatality, Goodwin et al found that unmarried people with cancer had a $23 \%$ reduced overall survival compared with married cancer patients. ${ }^{10}$ It has been suggested that psychosocial factors play a role in modifying the risk of cancer and also the prognosis of cancer once the disease has been diagnosed. ${ }^{10-12}$ It has been suggested, however, that ill health itself may cause some unmarried people to remain unmarried and that an increased risk of cancer or a reduced survival from cancer in unmarried women may reflect this particular selection bias. $^{13}$

In this study, we restricted analysis to women in their first marriage (married) and to never married (unmarried) middle aged Norwegian women. The main aims of the study were twofold. Firstly, we wanted to determine if there is any difference in risk of cancer between unmarried and married women. Secondly, we wanted to find out if unmarried women with cancer have a different overall and site specific survival than married patients.

\section{Methods}

All inhabitants in Norway have been assigned an 11 digit personal identification number and, since 1964, have been included in the central population register at the Central Bureau of Statistics. The bureau has used the personal identification number as the key to establishing individual marital and maternity histories of Norwegian women for the period 1964-84. Thus, the biography of marriages and births is nearly complete for all women born after $1935 .^{14}$

\section{CASES}

We restricted this study to women born between 1935 and 1954 (approximately 600000 ). They were individually linked to information on cancer incidence from the Norwegian cancer registry for the period 1966 to 1990 . Thus, all incident cases that occurred during this period were potentially eligible for the study. The cancer registry covers the whole population of Norway and registration is practically complete. ${ }^{15}$ The information includes data on cancer site, date of diagnosis, and stage at the time of diagnosis. Stage was classified according to clinical hospital reports and histological data. In the site specific analysis, stage was included as a covariate where this was appropriate, and in the overall analysis including all sites, we divided stage into localised and metastatic dis- 
Table 1 Odds ratio (OR) (95\% confidence interval (CI)) of cancer at specific sites in unmarried women compared with married women

\begin{tabular}{|c|c|c|c|}
\hline Cancer site & Cases/controls & Crude OR $(95 \%$ CI) & Age adjusted $O R(95 \% C I)$ \\
\hline $\begin{array}{l}\text { All cancer: } \\
\text { Married } \\
\text { Unmarried }\end{array}$ & $\begin{array}{c}12237 / 26079 \\
1466 / 2768\end{array}$ & $\begin{array}{l}1.00 \\
1 \cdot 13(1.06,1.21)\end{array}$ & $\begin{array}{l}1.00 \\
1.13(1.05,1.21)\end{array}$ \\
\hline $\begin{array}{l}\text { Breast: } \\
\quad \text { Married } \\
\text { Unmarried }\end{array}$ & $\begin{array}{c}3500 / 26079 \\
383 / 2768\end{array}$ & $\begin{array}{l}1.00 \\
1.03(0.92,1.15)\end{array}$ & $\begin{array}{l}1 \cdot 00 \\
1 \cdot 11(0.99,1.25)\end{array}$ \\
\hline $\begin{array}{l}\text { Cervix: } \\
\text { Married } \\
\text { Unmarried }\end{array}$ & $\begin{array}{c}1568 / 26079 \\
135 / 2768\end{array}$ & $\begin{array}{l}1.00 \\
0.81(0.68,0.97)\end{array}$ & $\begin{array}{l}1.00 \\
0.76(0.63,0.91)\end{array}$ \\
\hline $\begin{array}{l}\text { Ovary: } \\
\text { Married } \\
\text { Unmarried }\end{array}$ & $\begin{array}{l}971 / 26079 \\
171 / 2768\end{array}$ & $\begin{array}{l}1.00 \\
1.66(1.41,1.96)\end{array}$ & $\begin{array}{l}1.00 \\
1.68(1.42,1.99)\end{array}$ \\
\hline $\begin{array}{l}\text { Uterus: } \\
\text { Married } \\
\text { Unmarried }\end{array}$ & $\begin{array}{c}436 / 26079 \\
71 / 2768\end{array}$ & $\begin{array}{l}1.00 \\
1.53(1.19,1.97)\end{array}$ & $\begin{array}{l}1.00 \\
1.86(1.44,2.39)\end{array}$ \\
\hline $\begin{array}{l}\text { Colorectum: } \\
\text { Married } \\
\text { Unmarried }\end{array}$ & $\begin{array}{c}738 / 26079 \\
66 / 2768\end{array}$ & $\begin{array}{l}1.00 \\
0.84(0.65,1.09)\end{array}$ & $\begin{array}{l}1.00 \\
0.95(0.73,1.26)\end{array}$ \\
\hline $\begin{array}{l}\text { Malignant mel } \\
\text { Married } \\
\text { Unmarried }\end{array}$ & $\begin{array}{c}1438 / 26079 \\
149 / 2768\end{array}$ & $\begin{array}{l}1.00 \\
0.98(0.82,1.16)\end{array}$ & $\begin{array}{l}1.00 \\
0.89(0.75,1.06)\end{array}$ \\
\hline $\begin{array}{l}\text { Lung: } \\
\text { Married } \\
\text { Unmarried }\end{array}$ & $\begin{array}{c}255 / 26079 \\
25 / 2768\end{array}$ & $\begin{array}{l}1.00 \\
0.92(0.61,1.40)\end{array}$ & $\begin{array}{l}1.00 \\
1.04(0.69,1.57)\end{array}$ \\
\hline $\begin{array}{c}\text { Haematologica } \\
\text { Married } \\
\text { Unmarried }\end{array}$ & $\begin{array}{l}740 / 26079 \\
127 / 2768\end{array}$ & $\begin{array}{l}1.00 \\
1.62(1.34,1.96)\end{array}$ & $\begin{array}{l}1.00 \\
1.42(1.17,1.73)\end{array}$ \\
\hline $\begin{array}{l}\text { Thyroid cancer } \\
\text { Married } \\
\text { Unmarried }\end{array}$ & $\begin{array}{c}641 / 26079 \\
58 / 2768\end{array}$ & $\begin{array}{l}1.00 \\
0.85(0.65,1.12)\end{array}$ & $\begin{array}{l}1.00 \\
0.73(0.56,0.96)\end{array}$ \\
\hline $\begin{array}{l}\text { Brain tumours: } \\
\text { Married } \\
\text { Unmarried }\end{array}$ & $\begin{array}{l}621 / 26079 \\
110 / 2768\end{array}$ & $\begin{array}{l}1.00 \\
1.67(1.36,2.05)\end{array}$ & $\begin{array}{l}1.00 \\
1.55(1.25,1.92)\end{array}$ \\
\hline
\end{tabular}

ease. Age at diagnosis was divided into four categories, younger than $30,30-39,40-49$, and 50 years and older

This study consists of two parts. Firstly, we used a nested, case-control design to study the risk of cancer in unmarried women compared with married women. Unmarried women were defined as never married, and married women as women who had not previously been divorced or widowed. Secondly, we applied survival analysis and examined the risk of dying among unmarried and married cancer cases from the time of diagnosis until the end of follow up.

\section{RISK OF CANCER}

A total of 16951 incident cases of cancer diagnosed between 1966 and 1990 were identified among the population of women born between 1935 and 1954 . Nearly $40 \%$ of these cases were diagnosed between 1985 and 1990, and information on marital changes was not available for this period. This could mean that some women were misclassified as unmarried who had actually married between 1985 and 1990 . In the analysis, we assumed that this misclassification would affect cases and controls equally, and had not therefore caused a systematic bias in the estimates of relative risk.

In all, $839(4.9 \%)$ women were excluded because of coding errors, missing information, and emigration, leaving a total of 16112 eligible cases. For each incident case of cancer, we selected as controls two women from the total population with no diagnosis of cancer, whose marital and maternity histories were known. The controls were age matched to the cases, by identical year of birth, and there was a total of 34460 . After excluding widows and women who were separated or divorced, we used 12237 married and 1466 unmarried cases in the analysis. Similarly, 26079 married and 2768 unmarried controls were included.

The odds ratio (OR) was applied as a measure of relative risk of cancer for unmarried women, using married women as a reference. To adjust for a one year difference in age, we used the Mantel-Haenszel procedure in a stratified analysis. ${ }^{16}$ The Mantel-Haenszel $\chi^{2}$ statistic was used to calculate $95 \%$ confidence intervals (CI). In the analyses we used the computer program $S A S .{ }^{17}$

\section{SURVIVAL FROM CANCER}

In the survival analysis, we used death registry data made available from the central person register of the Central Bureau of Statistics. Each case of cancer was followed from the month of diagnosis (1966-90) until death or until the end of follow up, whichever event occurred first. Thus, the information included deaths from 1966 until the end of 1991. The latest update of the registry showed that 294 married cases had been reclassified as divorced, and these were excluded from the analysis, leaving 11943 married cases to be followed up. Among unmarried cases, there were 1473 eligible cases.

We analysed the data using the $\chi^{2}$ statistic to test differences in the stage at diagnosis between marital groups, and Kaplan-Meier analysis to test differences in survival. ${ }^{18}$ To control for potentially confounding factors such as age and stage at diagnosis in the multivariate analysis, 
Table 2 Hazard ratio (HR) (95\% confidence interval (CI)) of dying in unmarried women compared with married women. All women were born between 1935 and 1954 and diagnosed with cancer between 1966 and 1990

\begin{tabular}{|c|c|c|c|c|}
\hline Cancer site & No & Deaths & Crude HR (95\% CI) & Adjusted HR $(95 \% C I)^{*}$ \\
\hline $\begin{array}{l}\text { All cancer: } \\
\text { Married } \\
\text { Unmarried }\end{array}$ & $\begin{array}{r}11943 \\
1473\end{array}$ & $\begin{array}{r}3576 \\
592\end{array}$ & $\begin{array}{l}1.00 \\
1.44(1.32,1.58)\end{array}$ & $\begin{array}{l}1 \cdot 00 \\
1 \cdot 26(1 \cdot 15,1.39)\end{array}$ \\
\hline $\begin{array}{l}\text { Breast: } \\
\text { Married } \\
\text { Unmarried }\end{array}$ & $\begin{array}{r}3446 \\
385\end{array}$ & $\begin{array}{l}896 \\
127\end{array}$ & $\begin{array}{l}1.00 \\
1.32(1.10,1.59)\end{array}$ & $\begin{array}{l}1 \cdot 00 \\
1 \cdot 11(0.91,1.34)\end{array}$ \\
\hline $\begin{array}{l}\text { Cervix: } \\
\text { Married } \\
\text { Unmarried }\end{array}$ & $\begin{array}{r}1484 \\
134\end{array}$ & $\begin{array}{r}315 \\
45\end{array}$ & $\begin{array}{l}1 \cdot 00 \\
1 \cdot 79(1 \cdot 30,2 \cdot 46)\end{array}$ & $\begin{array}{l}1 \cdot 00 \\
1.48(1.05,2 \cdot 09)\end{array}$ \\
\hline $\begin{array}{l}\text { Ovary: } \\
\text { Married } \\
\text { Unmarried }\end{array}$ & $\begin{array}{l}945 \\
175\end{array}$ & $\begin{array}{r}327 \\
57\end{array}$ & $\begin{array}{l}1.00 \\
0.93(0.70,1.25)\end{array}$ & $\begin{array}{l}1.00 \\
0.92(0.68,1.26)\end{array}$ \\
\hline $\begin{array}{l}\text { Uterus: } \\
\text { Married } \\
\text { Unmarried }\end{array}$ & $\begin{array}{r}432 \\
69\end{array}$ & $\begin{array}{l}57 \\
13\end{array}$ & $\begin{array}{l}1.00 \\
1.55(0.85,2.83)\end{array}$ & $\begin{array}{l}1.00 \\
1.42(0.74,2.71)\end{array}$ \\
\hline $\begin{array}{l}\text { Colorectum: } \\
\text { Married } \\
\text { Unmarried }\end{array}$ & $\begin{array}{r}728 \\
67\end{array}$ & $\begin{array}{r}318 \\
32\end{array}$ & $\begin{array}{l}1 \cdot 00 \\
1 \cdot 20(0 \cdot 83,1 \cdot 74)\end{array}$ & $\begin{array}{l}1.00 \\
1.04(0.71,1.53)\end{array}$ \\
\hline $\begin{array}{l}\text { Malignant me } \\
\text { Married } \\
\text { Unmarried }\end{array}$ & $\begin{array}{r}1403 \\
149\end{array}$ & $\begin{array}{r}185 \\
25\end{array}$ & $\begin{array}{l}1.00 \\
1.37(0.90,2 \cdot 08)\end{array}$ & $\begin{array}{l}1.00 \\
1.50(0.95,2.36)\end{array}$ \\
\hline $\begin{array}{l}\text { Lung: } \\
\text { Married } \\
\text { Unmarried }\end{array}$ & $\begin{array}{r}253 \\
26\end{array}$ & $\begin{array}{r}200 \\
24\end{array}$ & $\begin{array}{l}1.00 \\
1.44(0.94,2.20)\end{array}$ & $\begin{array}{l}1 \cdot 00 \\
2 \cdot 06(1 \cdot 29,3 \cdot 30)\end{array}$ \\
\hline $\begin{array}{l}\text { Haematologic } \\
\text { Married } \\
\text { Unmarried }\end{array}$ & $\begin{array}{l}724 \\
129\end{array}$ & $\begin{array}{r}363 \\
87\end{array}$ & $\begin{array}{l}1 \cdot 00 \\
1 \cdot 64(1 \cdot 28,2 \cdot 11)\end{array}$ & $\begin{array}{l}1.00 \\
1.30(0.97,1.74) \dagger\end{array}$ \\
\hline $\begin{array}{c}\text { Thyroid cance } \\
\text { Married } \\
\text { Unmarried }\end{array}$ & $\begin{array}{r}609 \\
57\end{array}$ & $\begin{array}{r}26 \\
6\end{array}$ & $\begin{array}{l}1 \cdot 00 \\
3 \cdot 34(1 \cdot 22,9 \cdot 14)\end{array}$ & $\begin{array}{l}1 \cdot 00 \\
5 \cdot 18(1 \cdot 77,15 \cdot 11)\end{array}$ \\
\hline $\begin{array}{l}\text { Brain tumours } \\
\text { Married } \\
\text { Unmarried }\end{array}$ & $\begin{array}{l}606 \\
111\end{array}$ & $\begin{array}{r}250 \\
72\end{array}$ & $\begin{array}{l}1.00 \\
1.87(1.41,2.48)\end{array}$ & $\begin{array}{l}1.00 \\
1.38(0.98,1.92)\end{array}$ \\
\hline
\end{tabular}

* Hazard ratio adjusted for age at diagnosis and stage at diagnosis. In the analysis of all cancer, stage was dichotomised to localised disease and disease with metastasis.

t Hazard ratio adjusted for age at diagnosis.

the Cox regression model was used. ${ }^{18}$ We applied the computer program SPSS for the survival analysis. ${ }^{19}$

\section{Results}

Initially, we examined the risk of cancer between unmarried and married women for all cancers and for different sites (table 1). Overall, unmarried women had an increased risk $(\mathrm{OR}=1 \cdot 13,95 \% \mathrm{CI} 1 \cdot 05,1 \cdot 21)$ which could be attributed to cancer of the ovaries, uterus, brain, and haematological malignancies. For cervical cancer, unmarried

Table 3 Number of cancer patients with localised and metastatic disease at diagnosis in relation to marital status and age at diagnosis

\begin{tabular}{llrcrc}
\hline Stage at diagnosis & \multicolumn{2}{l}{ Age at diagnosis } & \multicolumn{2}{c}{ Married cases } & \multicolumn{2}{c}{ Unmarried cases } \\
& $(y)$ & No & $(\%)$ & No & $(\%)$ \\
\hline Localised disease & $\leq 29$ & 678 & $(8 \cdot 8)$ & 125 & $(14 \cdot 7)$ \\
& $30-39$ & 2902 & $(37 \cdot 6)$ & 349 & $(41 \cdot 1)$ \\
& $40-49$ & 3344 & $(43 \cdot 4)$ & 318 & $(37 \cdot 4)$ \\
Total & $\geq 50$ & 787 & $(10 \cdot 2)$ & 58 & $(6 \cdot 8)$ \\
Metastatic disease & & 7711 & $(100)$ & 850 & $(100)$ \\
& $\leq 29$ & & & & \\
& $30-39$ & 257 & $(6 \cdot 6)$ & 81 & $(14 \cdot 8)$ \\
& $40-49$ & 1289 & $(30 \cdot 9)$ & 198 & $(36 \cdot 1)$ \\
Total & $\geq 50$ & 2018 & $(48 \cdot 3)$ & 226 & $(41 \cdot 2)$ \\
& & 596 & $(14 \cdot 3)$ & 44 & $(8 \cdot 0)$ \\
\hline
\end{tabular}

Table 4 Relative risk of death for unmarried compared with married women diagnosed with cancer, in relation to the stage of disease

\begin{tabular}{lll}
\hline Stage of disease & $\begin{array}{l}\text { All cases } \\
\text { Crude } H R(95 \% C I)\end{array}$ & $\begin{array}{l}\text { All cases } \\
\text { Adjusted } H R(95 \% C I)^{*}\end{array}$ \\
\hline Localised disease & $1.58(1.37,1.83)$ & $1.42(1.22,1.66)$ \\
Metastatic disease & $1.27(1.13,1.42)$ & $1.18(1.05,1.33)$ \\
\hline
\end{tabular}

* Adjusted for age at diagnosis women had a lower risk than married women $(\mathrm{HR}=0.76$, 95\% CI $0.63,0.91)$. This was also observed for thyroid cancer $(\mathrm{OR}=0.73$, 95\% CI 0.56, 0.96).

In the survival analysis (table 2), unmarried cases had an overall $26 \%$ increased risk of dying compared with married cases $(\mathrm{HR}=1 \cdot 26,95 \%$ CI $1 \cdot 15,1 \cdot 39$ ), after adjustment for age and stage at diagnosis. The increased death rate among unmarried cases was seen for cervical cancer $(\mathrm{HR}=1 \cdot 48,95 \% \mathrm{CI} 1 \cdot 05,2 \cdot 09)$, lung cancer $(H R=2 \cdot 06,95 \%$ CI $1 \cdot 29,3 \cdot 30)$, and cancer of the thyroid $(\mathrm{HR}=5 \cdot 18,95 \% \mathrm{CI} 1 \cdot 77$, 15.11).

Table 3 shows the distribution of women with localised and metastatic disease in relation to marital status and age at diagnosis. In all, $65 \%$ of married cases had localised disease at diagnosis compared with $60.8 \%$ of unmarried cases $\left(\chi^{2}=13.83, p=0.002\right)$. Among unmarried women, a greater percentage was diagnosed in the younger age groups. These differences showed similar patterns both for localised $\left(\chi^{2}=46 \cdot 13, \mathrm{p}<0.001\right)$ and metastatic disease $\left(\chi^{2}=66.43, \mathrm{p}<0.001\right)$.

Table 4 shows that the higher death rate among unmarried cases was more evident for localised disease $(\mathrm{HR}=1.42,95 \% \mathrm{CI} 1 \cdot 22$, $1 \cdot 66)$ than for metastatic disease $(H R=1 \cdot 18$, 95\% CI 1.05, 1.33) (figure). For localised disease (table 5), there were increased hazard ratios for cervical $(\mathrm{HR}=1.96,95 \%$ CI 1.38 , $2 \cdot 78)$ and lung cancer $(H R=2 \cdot 09,95 \%$ CI $1 \cdot 03,4 \cdot 25)$. The risk of dying from breast and colorectal cancer was also higher in unmarried patients, but these associations were not statistically significant. 


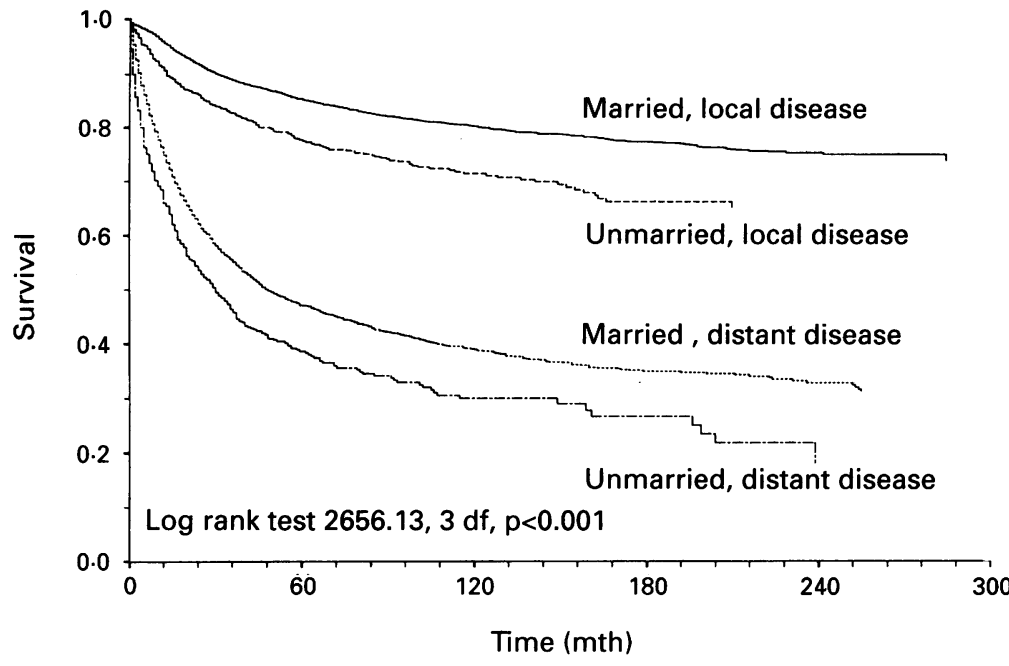

Total survival of localised and metastatic (distant) disease in married and unmarried women with cancer.

Table 5 Relative risk of death for unmarried compared with married women with localised disease at diagnosis in relation to cancer sites

\begin{tabular}{|c|c|c|}
\hline Cancer sites & Crude HR $(95 \%$ CI) & Adjusted $H R(95 \% C I)^{*}$ \\
\hline $\begin{array}{l}\text { Breast } \\
\text { Cervix } \\
\text { Ovaries } \\
\text { Uterus } \\
\text { Colorectum } \\
\text { Malignant melanoma } \\
\text { Lung }\end{array}$ & $\begin{array}{l}1.38(0.97,1.96) \\
1.84(1.30,2.61) \\
1.19(0.64,2.23) \\
1.05(0.44,2.48) \\
1.60(0.77,3.32) \\
1.18(0.68,2.05) \\
2.13(1.06,4.27)\end{array}$ & $\begin{array}{l}1.35(0.95,1.92) \\
1.96(1.38,2.78) \\
1.10(0.57,2.10) \\
0.87(0.34,2.23) \\
1.61(0.77,3.36) \\
1.16(0.66,2.01) \\
2.09(1.03,4.25)\end{array}$ \\
\hline
\end{tabular}

* Adjusted for age at diagnosis.
For uterine and ovarian cancer, nulliparity is an established risk factor and may account for the increased risk in unmarried women in our study. ${ }^{2127-29}$ Nulliparity may also partly explain the decreased risk of thyroid cancer in unmarried women, since Kravdal et al found that thyroid cancer risk increased with the number of pregnancies. ${ }^{30}$ This was not, however, confirmed in another Norwegian study. ${ }^{31}$ Parity has also been associated with colorectal cancer in some, but not in other studies. ${ }^{32-35}$

For brain tumours and haematological malignancies, other explanations may be more relevant than confounding with reproductive factors. Approximately $60 \%$ of unmarried women with brain tumours were diagnosed before 30 years of age, compared with $20 \%$ among married patients. For haematologic malignancies, $50 \%$ of unmarried patients were diagnosed before age 30 , and $27 \%$ among the married. This indicates that women who were diagnosed with these cancers at a relatively young age tend to remain unmarried, and this may be an example of the "marriage selection hypothesis". ${ }^{13}$ We therefore suggest that the estimated increased risk of brain and haematological malignancies among unmarried women can be attributed to selection bias.

\section{SURVIVAL FROM CANCER}

We found an increased case fatality among unmarried women with cancer of the cervix, lung, and thyroid, compared with married patients.

In a population based study of 27779 cancer cases, Goodwin et al found that the unmarried had a reduced total survival $(\mathrm{HR}=1 \cdot 23,95 \%$ CI $1 \cdot 19,1 \cdot 28$ ), which was explained by stage (unmarried persons were more likely to be diagnosed at a metastatic stage) and treatment (unmarried people were more likely to be untreated for cancer). ${ }^{10}$ After adjustment for stage and treatment, however, a poorer survival still persisted among unmarried people $(\mathrm{HR}=1 \cdot 18$, $95 \%$ CI $1.12,1.23)$. In another population based study of 4764 women with breast cancer, it was found that single women had a worse prognosis than married women $(\mathrm{HR}=1.34$, $95 \%$ CI $1 \cdot 10,1 \cdot 62) .{ }^{36}$ In a study of cervical cancer, Murphy et al found no association between being single and survival. ${ }^{37}$

For cervical cancer, we found that the proportion diagnosed with localised disease was higher $(p=0.04)$ in married patients, and this may indicate that unmarried women would tend to have a delayed diagnosis. For localised disease too, however, the relative risk of dying was higher among unmarried women $(\mathrm{HR}=$ $1 \cdot 96,95 \%$ CI $1 \cdot 38,2 \cdot 78)$. Thus, we found that unmarried women had a lower risk of cervical cancer, but their prognosis was poorer once the disease was present. It is possible that the latter finding is a result of delayed diagnosis. As for the lower risk among unmarried women, this has been found by others, and may suggest that risk factors related to sexual activity may be more prevalent in married than unmarried women. 
The stronger overall hazard ratio for localised than for distant disease may indicate a role for social factors. For distant disease, it can be assumed that biology will predominate in determining prognosis. ${ }^{5}$ For localised disease, socioeconomic status and psychosocial support may also be important, since these factors may be associated with differences in tumour characteristics, stage, and treatment. ${ }^{10-12}$

\section{Conclusion}

In conclusion, this study has shown that among middle aged Norwegian women, being unmarried carries a higher risk of uterine and ovarian cancer than being married. Nulliparity is a strong risk factor for these cancers, and may well explain the results. The increased risk of brain tumours and haematological malignancies among unmarried women may be caused by selection bias, where the disease may cause a substantial proportion of unmarried patients to remain unmarried. The lower survival among unmarried cancer patients, particularly from localised disease, may support the hypothesis that for metastatic disease, biology will predominate in determining the prognosis, but for localised disease, other factors such as socioeconomic status and social support may also be important.

This study was supported by grants no $90098 / 002$ from the Norwegian Cancer Society and no 363.91 from the Norwegian Research Council. We appreciate the advice and technical as sistance of Drs S Tretli and $\varnothing$ Kravdal and Mr R P Halle.

1 Coombs RH. Marital status and personal well-being: a literature review. Family Relations 1991;40:97-102.

2 Joung IMA, Van De Mheen H, Stronks K, Van Poppel FWA, Mackenbach JP. Differences in self-reported morbidity by marital status and by living arrangements. Int $\mathcal{F}$ Epidemio 1994;23:91-7.

3 Berkson J. Mortality and marital status. Reflections on the derivation of etiology from statistics. Am $\mathcal{f}$ Public Health 1962;52:1318-29.

4 Gove WR. Sex, marital status, and mortality. Am $\mathcal{f}$ Sociology 1973;79:45-67.

5 Cassileth BR, Lusk EJ, Miller DS, Brown LL, Miller C. Psychosocial correlates of survival in advanced malignant disease? N Engl f Med 1985;312:1551-5.

6 Sheps MC. Marriage and mortality. Am $f$ Public Health 1961;51:547-55.

7 Yoav BS, Smith GD, Shipley M, Marmot MG. Magnitude and causes of mortality differences between married and and causes of mortality differences between married and
unmarried men. $\mathcal{F}$ Epidemiol Community Health 1993;47: unmarried

8 Swanson GM, Belle SH, Satariano WA. Marital status and cancer incidence: differences in the black and white populations. Cancer Res 1985;45:5883-9.

9 Ernster VL, Sacks ST, Selvin S, Petrakis NL. Cancer incidence by marital status: US third national cancer survey. f Natl Cancer Inst 1979;63:567-85.
10 Goodwin JS, Hunt WC, Key CR, Samet JM. The effect of marital status on stage, treatment, and survival of cance patients. FAMA 1987;258:3125-30.

11 Broadhead WE, Kaplan BH, James SA, et al. The epidemiologic evidence for a relationship between social support and health. Am 7 Epidemiol 1983;117:521-37.

12 Kogevinas M, Marmot MG, Fox AJ, Goldblatt PO. Socioeconomic differences in cancer survival. $\mathcal{f}$ Epidemiol Comeconomic differences in cance

13 Goldman N. Marriage selection and mortality patterns: inferences and fallacies. Demography 1993;30:189-208.

14 Kvikstad A, Vatten LJ, Tretli S, Kvinnsland S. Death of husband or marital divorce related to risk of breast cancer in middle-aged women. A nested case-control study among Norwegian women born 1935-1954. Eur f Cancer 1994;30A:473-7.

15 Lund E. Mortality from ovarian cancer among women with many children. Int $\mathcal{f}$ Epidemiol 1992;21:872-6.

16 Rothman KJ. Modern epidemiology. Boston: Little, Brown and Company, 1986.

17 SAS Institute Inc. SAS Release 6.04. Cary, NC: SAS, 1990

8 Altman DG. Practical statistics for medical research. London: Chapman and Hall, 1991.

19 SPSS Inc, SPSS Release 6.0. Chicago, Illinois, USA, 1993.

20 Reynolds P, Kaplan GA. Social connections and risk for ceynolds P, Kaplan GA. Social connections and risk for
cancer: prospective evidence from the Alameda County study. Behav Med 1990;16:101-10.

21 Ewertz M. Breast cancer in Denmark. Incidence, risk factors, and characteristics of survival. Acta Oncol 1993;32 595-615.

22 Janerich DT, Hoff MB. Evidence for a crossover in breas cancer risk factors. Am $\mathcal{F}$ Epidemiol 1982;116:737-42.

23 Logan WPD. Marriage and childbearing in relation to cancer of the breast and uterus. Lancet 1953;ii:1199-201.

24 Beral V, Fraser P, Chilvers C. Does pregnancy protect against ovarian cancer? Lancet 1978; i: 1083-7.

25 Kvåle G, Heuch I, Nilssen S, Beral V. Reproductive factors and risk of ovarian cancer: a prospective study. Int $\mathcal{f}$ Cancer and risk of ovarian

26 Brinton LA, Fraumeni ir JF. Epidemiology of uterine cervical cancer. F Chron Dis 1986;39:1051-65.

27 Franceschi S. Reproductive factors and cancers of the breast, ovary and endometrium. Eur $\mathcal{F}$ Cancer Clin Oncol 1989; 25:1933-43.

28 Miller AB, Barclay THC, Choi NW, Grace MG, Wall C, Plante $\mathrm{M}$, et al. A study of cancer, parity and age at firs pregnancy. $\mathcal{F}$ Chron Dis 1980;33:595-605.

29 Kvåle G, Heuch I, Nilssen S. Reproductive factors and cancers of the breast and genital organs - are the different cancer sites similarly affected? Cancer Detect Prev 1991; 16:369-77.

30 Kravdal $\emptyset$, Glattre E, Haldorsen T. Positive correlation between parity and incidence of thyroid cancer: new evidence based on complete Norwegian birth cohorts. Int $\mathcal{f}$ ence based on complete

31 Akslen LA, Nilssen S, Kvåle G. Reproductive factors and risk of thyroid cancer. A prospective study of 63090 women from Norway. Br $\mathcal{F}$ Cancer 1992;65:772-4.

32 Kravdal $\varnothing$, Glattre E, Kvåle G, Tretli S. A sub-site-specific analysis of the relationship between colorectal cancer and parity in complete male and female Norwegian birth cohorts. Int $\mathcal{f}$ Cancer 1993;53:56-61.

33 Potter JD, McMichael AJ. Large bowel cancer in women in relation to reproductive and hormonal factors: a casecontrol study. $\mathcal{F}$ Natl Cancer Inst 1983;71:703-9.

34 Potter JD, Slattery ML, Bostick RM, Gapstur SM. Colon cancer: a review of the epidemiology. Epidemiol Rev 1993; 15:499-545.

35 Kvåle G, Heuch I. Is the incidence of colorectal cancer related to reproduction? A prospective study of 63000 related to reproduction? A prospective
women. Int $\mathscr{f}$ Cancer 1991;47:390-5.

36 Boffetta P, Merletti F, Winkelmann R, Magnani C, Cappa APM, Terracini B. Survival of breast cancer patients from Piedmont, Italy. Cancer Causes and Control 1993;4:209-15.

37 Murphy M, Goldblatt P, Thornton-Jones H, Silcocks P. Survival among women with cancer of the uterine cervix: influence of marital status and social class. 7 Epidemiol Community Health 1990;44:293-6. 